\title{
Perplexity and Countermeasures: the Analysis of the Elements of the Transformation and Development of New Universities
}

\author{
Huang Liang-Yong \\ Vocational and Technical Education College \\ Guangxi Science and Technology Normal University \\ Guangxi, Laibin, 546199 \\ huangliangyong@126.com
}

\begin{abstract}
The transformation and development of newlybuilt colleges and universities are the strategic measure of national higher education, which is an important guarantee for the upgrading of economic transformation and the supply-side structural reform. This paper summarizes and analyzes the main problems in the construction of new undergraduate colleges, explores the key elements and countermeasures in transformation and development, in order to provide references for the sustainable development of newly established universities.
\end{abstract}

Keywords-new undergraduate colleges; transformation and development; elements; application-oriented

\section{INTRODUCTION}

With the national economic and social adjustment of industrial structure and the strategic emerging industry transformation, and increasing needs of application-oriented, inter-disciplinary talent and innovative talents, in May 2014, the Party Central Committee and the State Council promulgated the "State Council on Accelerating the Development of Modern Occupation Education", which also clearly pointed out that it is important to cultivate a large number of high-skilled talents and improve the quality of talents, so it is urgent to guide a group of ordinary colleges and universities to change application and technical colleges, in order to promote regional economic and social development and increasing employment rate. In October 2015, the Ministry of education in conjunction with the National Development and Reform Commission, Ministry of Finance jointly issued the "guiding part of local colleges and universities to change the application guidance", clearly put forward: focus on innovation driven development, "2025 Chinese Manufacturing", "Internet plus", "The Belt and Road" Initiative, to enhance the ability of local colleges and universities in the service area economy, to solve the problems of structural contradictions in education, serious homogeneity and low quality of employment for graduates, cultivating technical talents, transform the school thought to serve local economic and social development and improve its ability to drive innovation. Since 2007, Guangxi has conducted two

Fund Project: Guangxi Occupation Education Reform Project: the late Development Region "Junior-Senior Middle School and Undergraduate University" Integration of Vocational Education Research and Practice in the Course of Education Science, and Guang xi "13th Five-Year" Plan of Guang xi Vocational Education Research Project: Research on Teacher Training in Guangxi Occupation Education. rounds of vocational education poverty, 2014, Guangxi issued "on the implementation of the" decision "of the State Council on accelerating the development of modern occupation education implementation opinions", pointed out the need to guide part of the pilot colleges to application-oriented colleges, encourage independent colleges to change the development ideas to construct a high-technology colleges.

In 2015, Guangxi Normal University of Science and Technology was approved to be a pilot University of transformation and development in Guangxi's newly-built undergraduate universities. Its transformation and development orientation are: based on the nature of normal education, develop to service vocational education, train the applied talents, and establish distinctive local applicationoriented universities. Through the transformation and development to adapt and integrate into the local new industry initiative and new business development, and strive to create a professional cluster of six characteristics, effectively promote the school to serve the local economic and social, cultivate applied talents to meet the practical needs. This thesis summarizes the university transformation in the development process of many factors as the breakthrough point, analysis of the various elements the problems and countermeasures are put forward, and provide the reference for the transformation and development of newly built undergraduate colleges.

\section{THE PROBLEM OF LOCAL NEWLY-BUILT UNDERGRADUATE COLLEGES AND UNIVERSITIES DURING THE TRANSFORMATION AND DEVELOPMENT PROCESS}

From 2005-2015, the number of ordinary higher education institutes increased from 1792 to 2560 , the number of students increased from 15, 617,000 and from 800 to 26,253,000 [1][2], and the scale of China's higher education development continues to expand. The trend of popularization of higher education brought it to a new stage. The development of higher education will make great changes in function classification, orientation, educational management mode, professional structure and personnel training mode, especially for, a local undergraduate college which occupies $95 \%$ of the total number of undergraduate colleges[3]. The transformation and development of local new undergraduate colleges and 
universities to applied undergraduate colleges and universities is the general trend, but the following problems are common.

\section{A. The Orientation of Running a School is not Clear Enough}

For a long time, China's institutions of higher learning "emphasize in theory but not in practice", it makes the newly established local universities have their own doubts and worries about their transformation and development. In addition, we should refer to the standards and requirements set up by the undergraduate colleges and universities in the transformation and orientation of the universities that are clear and transformation, and establish their own orientation and transformation direction. These results are caused: first, many of the newly-upgraded local colleges positioned itself as a teaching type, and oriented its development as research and teaching, it deepened the development of newly-built undergraduate colleges to the academic trend, prompted school personnel, focused on the development of scientific research, academic papers, and cultivated talents, but separated its mission of serving local economy and applying trained talents. [3] Second, due to lack of experience, the top-level design lacks effective experience and timeliness, the university development of is lagging behind industrial transformation and development, and talent training is lagging behind market demand.

\section{B. Lack of Experience in Undergraduate Management}

Teaching management is the key link to optimize the allocation of teaching resources and improve the teaching level and service consciousness of teachers. At the beginning of the construction, the new local universities have not formed the teaching management idea of the undergraduate level, in addition, lack of experience in the management mode, means and system. The level and structure of the teaching managers are uneven, the overall quality of the teaching management team is low, and the teaching and scientific research ability of the teachers is weak. As far as the basic teaching conditions are concerned, the lack of practical teaching ability, the poor atmosphere of students' autonomous learning and initiative learning also occurs a lot of problems in the transformation and upgrading of teaching management in newly-built universities.

\section{The Major Structure Needs to be Optimized}

The transformation and development of the professional structure of the local newly-built undergraduate colleges and universities mainly have the problems: regional characteristics and application characteristics are not obvious, and homogeneity characteristics are too significant. To solve these problems, some scholars believe that many major universities in China are separated from the actual situation of regional economy, lacking practical application connotation, and tend to be theorized and academic. [5] [6] Also some scholars pointed out that the new local undergraduate colleges and universities set up majors due to their own lack of experience, the development of education in the university under the transformation of demand pressure, experience excessive imitation of other universities, major structure, target from the regional industry need to cultivate major programs and personnel allocations, serious homogenization tendency. Therefore, how to optimize the major structure is an urgent problem to be solved in the new universities, it is the key embodiment of university running characteristics.

\section{The Construction of the Teacher Team is Lagging Behind}

In the construction of teaching staff, scholars generally believe that in the process of building a new local undergraduate college, there are several problems such as the application is not prominent, the structure is not reasonable, and the evaluation mechanism is in contradiction. Wang Zhehe believes that the goal of the construction of teachers is not clear, the guidance is not clear, and the contradiction is serious. [7] In the introduction process the academic level is considered as the basis, it is opposite to the application of school characteristics and contradiction in teachers' evaluation process, also focuses on the measure of academic level, rather than the practice teaching ability; on the other hand, the lack of guidance and integrity of the teachers' training, enhance the theory ability of teachers and lack of practice, not for the practice of teaching to enhance the ability of overall planning. Some scholars believe that the school still lacks the reasonable mechanism to guide the teachers to go out and to improve the practical ability in the enterprises. [8] In addition, the low level of university running and weak funds lead to the difficulty and loss of high level teachers, which are also the main factors that lag behind the construction of teachers' team.

\section{THE ANALYSIS AND COUNTERMEASURES OF THE ELEMENTS OF THE TRANSFORMATION AND DEVELOPMENT OF THE NEWLY BUILT COLLEGES AND UNIVERSITIES}

In order to ensure the transformation development of new local colleges, response correctly to the serious problems in the transformation process, now provide some ideas to the new local undergraduate colleges in the process of transformation and development on how to grasp the orientation and top-level design, how to optimize the specialty structure, support the major and talent cultivation by major system, innovate the curriculum content and teaching mode to release teaching vitality, construct full-time and part-time parallel teachers to provide education and talent guarantee.

\section{A. Clear About the Education Orientation, Decide the \\ Transformation Top-level Design Transformation}

In the transformation process, the local new universities must make the development orientation after the transformation clearly. From the research on the new transformation and development of many scholars, it can be seen that the orientation of university running after the transformation is to serve the local economy and cultivate the applied talents. The running process of new universities must be combined to serve the local economic development in transition, based on their own advantages to fully interact with the local economic development in disciplines layout and to meet the national requirements and the needs of local and professional development of major cluster.

On this basis, the newly-built local undergraduate colleges in the university running orientation should be clear in two aspects: on one hand, Xu Guoqing pointed out that in the educational level of the positioning technology application type undergraduate colleges, the educational type is between undergraduate and higher vocational colleges, but it does not 
mean that the level is lower than the development orientation of undergraduate research. For more high-level talents the breakthrough of master education nature is the education content breakthrough, namely the technology research [9]; on the other hand, should get rid of four class classifications model commonly used in universities, avoid the academic training, orient the development combined with the "teaching type" and "application type", tend to applied talents, develop a new classification of teaching application.

Local colleges shall focus on the goal of serving the local economy, layout the reasonable discipline and orient the goal of training talents, explore the special advantage of local economy development of local economy, develop the discipline advantage around the characteristics, format the dislocation development mechanism to old undergraduate university. Furthermore, identify the talent cultivation orientation to avoid imitation research universities in the educational process, adhere to the training location for the fusion in order to cultivate talents of theoretical knowledge and application skills, cultivate high-quality talents to serve the local economy.

\section{B. Optimize the Major Structures and Meet the Needs of the Local Industry}

The key of newly-built local undergraduate faculty of survival and development is not only to adapt to the transformation of economic and social development, but also improve the education quality and enhance the unique connotation and the core competitiveness of universities through declaration and establishment of new major, major institutions optimization and major cluster building to enhance the unique connotation and the core competitiveness of universities, in order to promote the development of a comprehensive restructure.

- Increase the construction of new majors. On the basis of subject construction, properly declare and build new undergraduate majors on the basis of majors development. In the train of thought, actively explore the local characteristics, cultural resources, natural resources and industrial chain, properly set appropriate advanced majors to ensure sustainable major development; in terms of resources, universities shall set up a new major declaration of special funds for new major construction and related supporting experimental conditions; in the assessment process, introduce the industry and education expert review mechanism, establish major guidance committee mechanism to ensure the integrity, foresight and practical of major establishment.

- Strengthen the construction of major cluster. According to the main task and needs of national development, strive to build in line with the major cluster of university characteristics, in major cluster each major fully links with the regional post demand. Based on elimination mechanism, continuously optimize the major group and post demand platform for discipline cluster required to adapt the formation and development of local economy and society.

\section{Build up a Cooperative Education Platform and Deepen the Cooperation of Production, University and Research}

- Construct the talent training model. Base on the need of talents in the production process of the industrial chain, construct the training mode of applied talents "production connecting education, curriculum content matching production standards, the teaching process relating the production process", invites companies to jointly develop personnel training plan, proof the content together with enterprises, the formation of "cooperative education mechanism".

- Optimize the application course system. Through university-enterprise cooperation, colleges and universities shall realize the innovation application curriculum system with curriculum resources intensify, major construction branding and modernization of teaching methods modernization. In the personnel training process, not only pay attention to master the basic major knowledge, but also training talents' practical ability and innovation ability, build a modern apprenticeship with enterprises together to train high technical talents what economic restructure needs.

- Deepen the construction of university-enterprise cooperation. The new local undergraduate colleges and universities should strengthen cooperation with enterprises, support enterprises directly involved in the course of application of curriculum setting and let enterprises involve in teaching, to open a breakthrough major limitations, seek new breakthroughs in personnel training and scientific research cooperation, establish the new management mode of project management, teacher management, job evaluation and other aspects flexibly, to make management mode to adapt to the need for cooperation better.

\section{Change the idea of teaching and learning, explore new teaching methods}

As a newly-built local colleges, the teaching idea shall not be guided by the knowledge any more but by social demand, shall change from knowledge-based to competency-based, from theory-oriented to practice-oriented, from teachercentered to student-centered, changing from fixed and closed system to open and flexible independent teaching the teaching system. In the transformation process, give full play to the advantages of university-enterprise cooperation, joint production process post ability need, refine technical skills needed on each process as capacity factors, construct of training case curriculum aimed at the ability factors, provide the project case-based curriculum resource library with industry and major specialty in university-enterprise cooperation to transform the traditional philosophy of education.

\section{E. Set up subject and team to improve the structure of Double-Teachers}

In the process of overall transformation of new local universities, how to turn the whole faculty to "applicationoriented" is one of the key factors for the successful 
transformation of universities. In this process, teachers should make the following changes:

First of all, through the multiple channels allow teachers to go out, also let the teacher come in. Through cooperation, strive for batches of existing teachers every year to arrange their work line of business or practice for a period of time, the new teachers request relevant internship over a period of time before they come to posts, at the same time provide the opportunity to learn their teaching skills in China or overseas, encourage to introduce enterprises talents as part-time teachers to construct special teaching work to construct the application team with teachers working in full-time and part-time;

Secondly, change the mind. Change the existing teachers on the inherent teaching mode, teaching ideas, education concept understanding, during the teaching process, combined with their own major specialty and practical experience, change their teaching methods, instead of combining with practice teaching methods;

Thirdly, train double-qualified teachers and encourage qualified teachers to apply for corresponding major qualification certificates, and train teachers with dual qualification and dual capabilities as their individual career planning. In the construction of teacher evaluation system, multiple considerations are taken to establish an adjustable evaluation mechanism based on the characteristics of teachers to stimulate the vitality of the teachers.

Finally, we should expand and strengthen the discipline and major clusters, and create a unique brand of local undergraduate colleges through the overall planning of university and the construction of major clusters and integrate local resources, and create their own advantages in scientific research, professional title review and learning promotion. In addition, in the process of local investment, in some projects types needing highly skilled talents, form mechanism of cooperation between local enterprises and local universities, the universities are the carrier, the high skilled talents engage in the project itself into the college teaching management system. Through a multidimensional mechanism, realize the overall transformation of the "applied" teacher team.

\section{ACKNOWLEDGMENT}

This work is supported by Guangxi Occupation Education Reform Project: the late Development Region "Junior-Senior Middle School and Undergraduate University" Integration of Vocational Education Research and Practice in the Course of Education Science; Guangxi "13th Five-Year" Plan of Guangxi Vocational Education Research Project: Research on Teacher Training in Guangxi Occupation Education.

\section{REFERENCES}

[1] Website of Ministry of education.2015 National Statistics Bulletin of Education Development [EB/OL]. (2016-7-06) Http://www.moe.edu.cn/srcsite/A03/s180/moe_633/201607/t20160706_ 270976.html.

[2] Website of Ministry of Education.2005 National Statistics Bulletin of Education Development [EB/OL]. (2006-05).

Http://www.moe.gov.cn/s78/A03/ghs_left/s182/moe_633/tnull_15809.ht $\mathrm{ml}$.

[3] Liu Jun. Economic and Social Development Transformation and Teaching Service Type University Construction [J]. Higher Education Research, 2013, (08): 1-9. (In Chinese)

[4] Bian Liang. Problems and Countermeasures in the Development of New Undergraduate Universities in China. Based on the Analysis of the National Basic Database of Teaching in Universities in China, [J]. Modern Education Management, 2015, (10): 53-57. (In Chinese)

[5] Liang Dan, Xu Han. Research Status of the Transformation and Development of Local Undergraduate Colleges and Universities and Thinking on the [J]. Vocational Education Forum, 2015, (01): 37-41. (In Chinese)

[6] Wu Song, Xia Jianguo. Research on the Construction of Curriculum System under the Goal of Training Applied Undergraduate Talents [J]. Contemporary Vocational Education, 2016, (08): 10-14. (In Chinese)

[7] Wang Zhehe. The Dilemma and Countermeasures of Transformation and Development of New Local Universities. Based on the Perspective of Higher Education Governance Modernization, $[\mathrm{J}]$., Chinese Higher Education Research, 2015, (04): 53-59. (In Chinese)

[8] Liang Dan, Xu Han. Research Status of the Transformation and Development of Local Undergraduate Colleges and Universities and Thinking on the [J]. Vocational Education Forum, 2015, (01): 37-41. (In Chinese)

[9] Xu Guoqing. The connotation of Undergraduate Education in Technical Application Courses [J]. Jiangsu High Education, 2014, (06): 11-14. (In Chinese) 